\author{
Anna Baranowska-Rataj \\ Instytut Statystyki i Demografii \\ Szkoła Główna Handlowa w Warszawie; \\ anna.baranowska@sgh.waw.pl \\ Wydział Socjologii, \\ Uniwersytet Umeå \\ anna.baranowska@soc.umu.se \\ Maja Rynko \\ Instytut Badań Edukacyjnych \\ m.rynko@ibe.edu.pl
}

\title{
DOSTOSOWANIE SPOSOBU ORGANIZACJI CZASU PRACY DO OBOWIĄZKÓW RODZINNYCH W POLSCE
}

\begin{abstract}
WSTĘP
Posiadanie dzieci jest dla Polaków jedną z najważniejszych wartości (Pongracz i Spèder 2008, Stankuniene i Maslauskaite 2008). W świetle badań dotyczących intencji prokreacyjnych Polacy chcieliby mieć przeciętnie co najmniej dwójkę dzieci (Baranowska 2007, Titkow i Duch-Krzystoszek 2009, Mynarska, 2011). Planując posiadanie potomstwa, przyszli rodzice biorą pod uwagę jednak nie tylko swoje pragnienia i potencjalną satysfakcję, jaką może dać im rodzicielstwo, ale także koszty powiększenia rodziny. Można wskazać dwa główne typy kosztów posiadania dzieci: koszty bezpośrednie, związane z nakładami finansowymi na wychowanie dziecka oraz koszty pośrednie, tzw. koszty utraconych korzyści. Koszty pośrednie powstają, gdy rodzice rezygnują w całości lub w części z pracy zawodowej w celu opieki nad dzieckiem. Obejmują więc utracone dochody z pracy, a także deprecjację kapitału ludzkiego związaną z przerwą w wykonywaniu zawodu.

Koszty pośrednie posiadania dzieci są wyższe w tych krajach, w których występuje silny konflikt pomiędzy pracą zawodową kobiet a opieką nad dziećmi. Matysiak (2011) wskazuje trzy główne źródła tego konfliktu. Pierwsze źródło dotyczy niedo-
\end{abstract}


stosowania rozwiązań polityki rodzinnej do potrzeb osób, które chcą łączyć pracę zawodowej z opieką (np. niedorozwój opieki instytucjonalnej nad dziećmi). Drugim, nie mniej istotnym źródłem, są warunki świadczenia pracy, które utrudniają łączenie obowiązków zawodowych ze zobowiązaniami rodzinnymi. Można tu wskazać przede wszystkim takie bariery jak sztywne godziny pracy, ograniczone możliwości pracy w niepełnym wymiarze lub pracy poza firmą. Trzecim źródłem konfliktu pomiędzy pracą zawodową kobiet a opieką nad dziećmi są funkcjonujące w społeczeństwie normy kulturowe określające podział obowiązków pomiędzy kobietami i mężczyznami, w rodzinie i poza rodziną.

Wyższe koszty pośrednie i silny konflikt pomiędzy pracą zawodową kobiet a zobowiązaniami rodzinnymi zniechęcają do rodzicielstwa. W świetle wyników badań międzynarodowych, w krajach, w których rodzice nie mają odpowiednich warunków, by aktywnie uczestniczyć w rynku pracy, kobiety częściej opóźniają decyzje o macierzyństwie oraz rezygnują z pełnej realizacji planów prokreacyjnych (Baranowska i Matysiak 2012, McDonald 2006). W tym kontekście można się spodziewać, że zmniejszenie konfliktu pomiędzy posiadaniem dzieci a pracą zawodową kobiet mogłoby przyczynić się do wzrostu płodności w Polsce.

$\mathrm{W}$ niniejszym artykule skupiamy się na ocenie jednego z wyżej wymienionych źródeł konfliktu pomiędzy pracą zawodową kobiet a opieką nad dziećmi, który jest związany z rynkiem pracy w Polsce. Upowszechnienie rozwiązań uelastyczniających organizację obowiązków zawodowych jest obecnie postrzegana jako jeden z ważniejszych celów polityki rynku pracy i polityki rodzinnej ukierunkowanych na godzenie pracy i życia pozazawodowego (Machol-Zajda 2008, Kotowska, Sztanderska, Wóycicka 2009).

Rozpatrujemy następujące rozwiązania służące dostosowaniu organizacji pracy do obowiązków rodzinnych:

- pracę w niepełnym wymiarze czasu pracy,

- elastyczny czas pracy,

- wykonywanie pracy $\mathrm{z}$ domu ${ }^{1}$.

Zmniejszenie wymiaru czasu pracy jest postrzegane często jako jedna z opcji rozwiązania konfliktu pomiędzy karierą zawodową a rodziną (Matysiak 2011, Skarzyński 2007). Uważa się, że w krajach Europy Zachodniej wzrost zatrudnienia kobiet w dużej mierze wiąże się z możliwością ograniczenia czasu pracy przez matki wychowujące małe dzieci, które nie muszą rezygnować z aktywności zawodowej (OECD 2001). Umożliwia to utrzymanie kontaktu ze środowiskiem zawodowym. $\mathrm{Z}$ kolei wadą pracy w niepełnym wymiarze wobec pracy w pełnym wymiarze jest obniżenie dochodów rodziny związane ze zmniejszeniem podaży pracy oraz ryzyko niższych szans na awans związane ze zmniejszonym zaangażowaniem w pracę

1 W literaturze przedmiotu urlopy macierzyńskie, wychowawcze i opiekuńcze są rozpatrywane jako jeden z ważniejszych elementów systemu rozwiązań instytucjonalnych łączenia pracy zawodowej z obowiązkami rodzinnymi, nie są one jednak rozwiązaniem z zakresu organizacji pracy, dlatego zostaną pominięte w tym artykule. 
zawodową. Między innymi dlatego w Polsce, kobiety wychowujące małe dzieci rzadko wybierają zatrudnienie w niepełnym wymiarze (Matysiak 2011, Matysiak i Steinmetz 2005, OECD 2001). Znacznie częściej pracują w pełnym wymiarze lub opuszczają rynek pracy.

Drugim rozwiązaniem, które w przeciwieństwie do pracy w niepełnym wymiarze czasu nie wiąże się bezpośrednio z negatywnymi konsekwencjami finansowymi dla rodziny jest elastyczny czas pracy. Rozwiązanie to może być stosowane w ramach „tradycyjnego” stosunku pracy, np. przez wydłużanie okresów rozliczeniowych czasu pracy lub też wprowadzanie specjalnej kategorii umów o pracę w skompresowanym tygodniu pracy, czy też w ruchomym lub zadaniowym czasie pracy (Skarzyński 2007). W niektórych krajach - w tym w Polsce - pracodawcy mogą wprowadzać ruchomy czas pracy, kiedy to sam pracownik swobodnie decyduje o godzinie rozpoczęcia i zakończenia pracy przy zachowaniu ośmiogodzinnego czasu pracy w ciągu dnia (Riedman et al. 2006). Pracodawcy wykorzystujący ruchomy czas pracy dla potrzeb swoich pracowników mogą ustalić przedział czasu tzw. obecności obowiązkowej, w którym wszyscy pracownicy muszą być obecni w pracy (Skarzyński 2007). Ruchomy czas pracy ułatwia godzenie pracy z obowiązkami rodzinnymi pracowników, nie stwarza jednak przymusu zmiany zachowań - pracownik może przychodzić do pracy w tym samym czasie co dotychczas lub zmienić godziny przyjść (Sadowska-Snarska 2007). W pewnych krajach dopuszcza się także rozwiązanie określane, jako indywidualne konta czasu pracy, które pozwalają pracownikom skracać czas pracy w dni, w których wymagają tego obowiązki rodzinne i wyrównywać przepracowana liczbę godzin w dni, gdy konieczność ich zaangażowania w obowiązki rodzinne jest mniejsza. W Polsce wybrane metody elastycznej organizacji pracy są usankcjonowane prawnie, jednak - jak pokazujemy - nadal są one stosunkowo rzadko wykorzystywane w praktyce.

Innym rozwiązaniem, które może ułatwiać łączenie pracy zawodowej z opieką nad dziećmi i nie wiąże się ze zmniejszeniem podaży pracy, jest wykonywanie pracy poza przedsiębiorstwem. Praca z domu może oszczędzać czas dojazdów i umożliwiać dostosowanie czasu wykonywania pracy do indywidualnych potrzeb (w tym związanych z potrzebami małego dziecka). Z drugiej strony, praca z domu może obniżać koncentrację na obowiązkach zawodowych i wiązać się z trwałym odseparowaniem pracownika od środowiska pracy. Należy także zaznaczyć, że praca z domu może mieć negatywne aspekty także z perspektywy pracodawców, którzy stają wobec utrudnień nadzorowania i weryfikacji nakładu pracy oraz zaangażowania pracujących (Venkatesh i Vitalari 1992). Ponadto wykorzystanie tej formy zatrudnienia jest możliwe tylko w niektórych sektorach gospodarczych i grupach zawodowych. Są one mniej rozwinięte w Polsce niż w krajach zachodnioeuropejskich. Jest to jeden $\mathrm{z}$ powodów niskiego odsetka zatrudnionych w Polsce korzystających $\mathrm{z}$ telepracy.

Warto wspomnieć, iż możliwość łączenia pracy zawodowej z obowiązkami rodzinnymi jest elementem koncepcji ,godnej pracy” (decent work) propagowanej 
i monitorowanej przez Międzynarodową Organizację Pracy (ILO). Zgodnie z tą koncepcją organizacja czasu pracy powinna, między innymi, zapewniać zdrowie, bezpieczeństwo, równość płci pracowników, a także być ,przyjazną rodzinie” i pozwalać pracownikom wywierać wpływ na decyzje o godzinach pracy. Dokumenty Międzynarodowej Organizacji Pracy podkreślają, że długie i nietypowe godziny pracy (np. wieczorami lub w weekendy) wpływają negatywnie na życie rodzinne. Jednocześnie wskazuje się, iż to właśnie wymienione powyżej trzy główne rozwiązania: praca w niepełnym wymiarze, elastyczne godziny pracy oraz telepraca, powinny być promowane (por. np. Boulin et al. 2006).

W artykule przedstawiamy diagnozę obecnych możliwości dostosowywania organizacji czasu pracy do obowiązków rodzinnych w Polsce. Czynimy to w perspektywie porównawczej, odwołując się do danych dla innych krajów europejskich. Pokazujemy, na ile uwarunkowania i możliwości dostosowywania organizacji czasu pracy do obowiązków rodzinnych w kraju uległy poprawie w ostatnich latach tj. po 2005 roku. Wskazujemy także te elementy polityki rynku pracy, które mogłyby zostać zmodyfikowane $\mathrm{w}$ celu polepszenia możliwości łączenia pracy zawodowej i obowiązków rodzinnych.

\section{POLSKA W PERSPEKTYWIE PORÓWNAWCZEJ}

Dane wykorzystane $\mathrm{w}$ poniższym opracowaniu pochodzą głównie $\mathrm{z}$ badania Labour Force Survey (LFS), czyli Badania Aktywności Ekonomicznej Ludności (BAEL), oraz z realizowanego w II kwartale 2010 r. przy LFS/BAEL badania modułowego „Praca a obowiązki rodzinne”. Badanie to zostało przeprowadzone we wszystkich krajach Unii Europejskiej pod nazwą „Reconciliation between work and family life" według ujednoliconej metodologii opracowanej przez Eurostat. Przedstawione poniżej wyniki odnoszą się do wymienionych we wstępie trzech aspektów organizacji czasu pracy kluczowych dla godzenia życia prywatnego i zawodowego: pracy w niepełnym wymiarze, elastyczności czasu pracy oraz telepracy. Analiza stopnia elastyczności organizacji czasu pracy na podstawie danych modułu BAEL jest zawężona do populacji pracowników najemnych (zgodnie z zakresem danych tego modułu). Osoby samozatrudnione cechują się zazwyczaj zdecydowanie większą swobodą w zakresie ustalania godzin pracy. Przytaczamy także ogólne statystyki dotyczące pracujących w niepełnym wymiarze oraz telepracowników, które obejmują także osoby o statusie samozatrudnionego. Większość statystyk dotyczy kobiet w wieku 25-49 lat, które uzupełniamy analogicznymi statystykami dla populacji osób w wieku 15-64 lat. Takie zestawienie pozwala na ocenę, czy z rozważanych rozwiązań dostosowywania organizacji czasu pracy do obowiązków rodzinnych korzystają $\mathrm{w}$ równym stopniu kobiety i mężczyźni w różnym wieku, czy też są to rozwiązania służące głównie kobietom w wieku, w którym najczęściej wychowują dzieci. 
Dostosowanie sposobu organizacji czasu pracy do obowiązków rodzinnych $w$ Polsce

\section{ZMNIEJSZANIE WYMIARU CZASU PRACY}

W wielu krajach Europy Zachodniej wychowywanie małych dzieci wiąże się często z ograniczeniem wymiaru czasu pracy przez jednego z rodziców (Wykres 1). Wyraźnie wyróżniającym się krajem jest Holandia, gdzie z tego rozwiązania korzysta $60 \%$ par wychowujących dzieci. Wysoki, ponad 40-procentowy odsetek takich par można także zaobserwować w krajach niemieckojęzycznych. W Polsce odsetek ten wynosi zaledwie $6,7 \%$, a więc o około 11 punktów procentowych mniej niż w krajach UE ogółem. Jednocześnie wyższy jest odsetek par, które wychowują dziecko, pracując w pełnym wymiarze czasu pracy i odsetek par, w których tylko jeden z rodziców posiada pracę. Można więc stwierdzić, że w Polsce utrzymuje się polaryzacja aktywności zawodowej matek - obserwujemy niskie zatrudnienie w niepełnym wymiarze przy stosunkowo wysokim odsetku kobiet niepracujących i dość wysokim udziale kobiet łączących pracę $\mathrm{w}$ pełnym wymiarze $\mathrm{z}$ wychowywaniem dzieci (por. Aliaga 2005, Kotowska 2005).

Wykres 1. Ekonomiczne modele rodziny wśród par wychowujących dzieci w wieku 0-14 lat w $2008 \mathrm{r}$.

Figure 1. Employment patterns among couple families with children aged 0-14, 2008

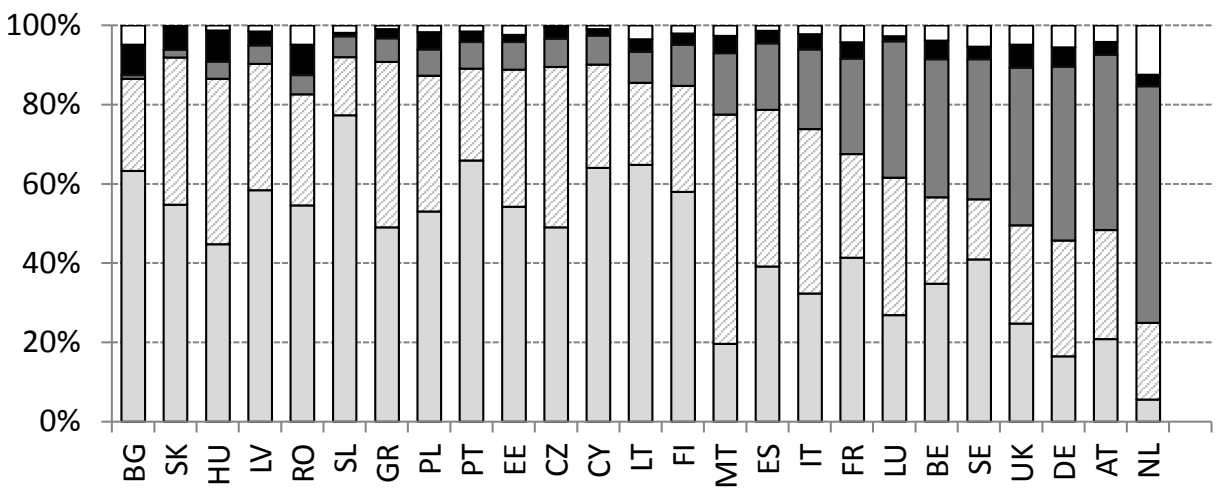

$\square$ oboje rodzice pracują w pełnym wymiarze

$\square$ jeden z rodziców pracuje w pełnym wymiarze

$\square$ jeden z rodziców pracuje w pełnym wymiarze, drugi w niepełnym

- oboje rodzice są bez pracy

$\square$ inne

Źródło: OECD Family Database. Uwaga: pojęcie pary dotyczy kobiety i mężczyzny mieszkających w tym samym gospodarstwie domowym.

Source: OECD Family Database. Note: couples are defined as men and women living in the same household. 
Przedstawione wzorce zatrudnienia w rodzinie są ściśle związane z powszechnością zatrudnienia w niepełnym wymiarze czasu pracy (Wykres 2). Spośród osób pracujących w wieku 15-64 lat w Holandii blisko połowa, a w Niemczech, Austrii, Wielkiej Brytanii, Szwecji i Belgii jedna czwarta zatrudniona jest w niepełnym wymiarze czasu pracy. W grupie krajów Europy Środkowo - Wschodniej odsetek pracujących w niepełnym wymiarze nie przekracza 10\% zatrudnionych. Jeszcze większe zróżnicowanie obserwuje się, porównując charakter zatrudnienia kobiet w grupie wieku 25-49 lat: w Holandii odsetek kobiet pracujących na część etatu sięga 70\%, zaś w Szwajcarii, Niemczech i Austrii - 45\%, podczas gdy w Polsce kształtuje się na poziomie $8,1 \%$ i nie odbiega od udziału osób pracujących na część etatu w populacji pracujących ogółem (Wykres 2).

Wykres 2. Odsetek pracujących w niepełnym wymiarze czasu pracy w krajach Unii Europejskiej w $2010 \mathrm{r}$.

Figure 2. The share of part-time employed in the European Union countries in 2010

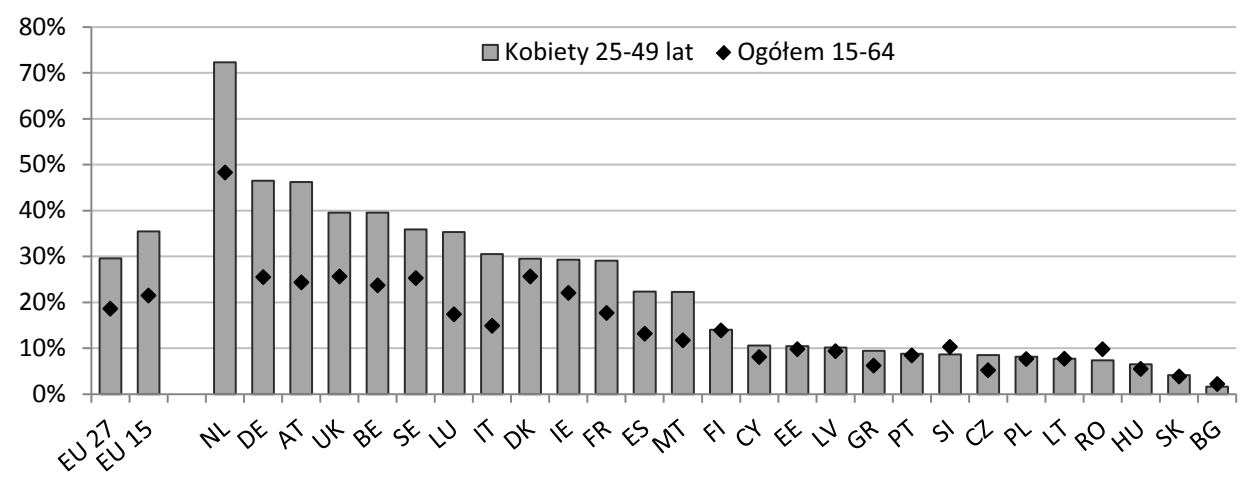

Źródło: opracowanie własne na podstawie danych Eurostat (stan na dzień 14.01.2013); dane roczne EU LFS

Source: own calculations based on Eurostat data (downloaded on $14^{\text {th }}$ January 2013); EU LFS annual results

http://epp.eurostat.ec.europa.eu/portal/page/portal/employment_unemployment_lfs/data/ database

Wyniki Badania Aktywności Ekonomicznej Ludności z II kwartału 2010 r. wskazują, że powodem pracy w niepełnym wymiarze czasu pracy co piątej kobiety $(21,4 \%)$ w grupie wieku 25-49 lat jest opieka nad dziećmi lub innymi osobami. Blisko jedna trzecia kobiet $(30,8 \%)$ pracujących w niepełnym wymiarze czasu pracy świadomie decyduje się na to rozwiązanie, a 26,1\% kobiet podejmuje pracę na część etatu z powodu problemów ze znalezieniem pracy w pełnym wymiarze czasu pracy. Co więcej, 41,5\% ogółu kobiet w wieku 25-49 lat pracujących w niepełnym wymiarze czasu pracy chciałoby pracować więcej godzin tygodniowo (zwiększając jednocześnie swoje zarobki). Wyniki te świadczą, iż praca w niepełnym wymia- 
rze czasu pracy nie tylko jest w Polsce rzadko stosowaną formą zatrudnienia, ale $\mathrm{w}$ wielu przypadkach jest również rozwiązaniem niezgodnym z preferencjami kobiet. Obserwowany w Polsce niski odsetek kobiet pracujących na część etatu nie wynika prawdopodobnie w większości przypadków z preferencji dotyczącej wymiaru czasu pracy, a raczej z konieczności związanej z małą dostępnością takiej formy zatrudnienia (Matysiak 2007, Głogosz 2007, Matysiak i Steinmetz 2008).

\section{ELASTYCZNY CZAS PRACY}

Kolejnym ze sposobów lepszego dostosowania organizacji obowiązków zawodowych do sytuacji rodzinnej, który nie wiąże się ze zmniejszeniem finansowego wynagrodzenia pracowników, jest stosowanie elastycznego czasu pracy. W Europie pod względem częstości elastycznych rozwiązań w zakresie organizacji czasu pracy wyróżniają się kraje nordyckie: Finlandia, Szwecja i Dania (a także kraje nienależące do UE - Norwegia i Islandia) oraz Niemcy i Austria. Polska należy do grupy krajów, w których rozwiązania pozwalające na przynajmniej częściowe uelastycznienie czasu pracy są stosowane stosunkowo rzadko. Odsetek pracowników najemnych w wieku 15-64 lat pracujących według sztywnych godzin określonych przez pracodawcę jest w Polsce dwukrotnie wyższy niż w Finlandii (87,6\% wobec 43,9\%) i o ponad 30 p.p. wyższy niż w Niemczech i w Szwecji. Kraje, w których częstość elastycznych rozwiązań dotyczących organizacji czasu pracy jest niższa niż w Polsce, to przede wszystkim kraje Europy Środkowo-Wschodniej: Litwa, Słowacja, Rumunia, Bułgaria, Węgry, Łotwa oraz kraje iberyjskie - Portugalia i Hiszpania (Wykres 3).

Rozwiązania z zakresu organizacji czasu pracy dopuszczające pewną elastyczność obejmują, między innymi, możliwość miesięcznego rozliczania przepracowanych godzin (zakładając określoną liczbę godzin do przepracowania w miesiącu), często określaną jako flexitime, oraz możliwość zmiany (przynajmniej częściowej) godzin rozpoczęcia lub zakończenia dnia pracy przy przyjętej dziennej liczbie godzin pracy. W żadnym europejskim kraju elastyczne formy organizacji pracy nie są jednak dominującymi rozwiązaniami, także w przypadku zawężenia analizowanej grupy do pracujących kobiet w wieku 25-49 lat (Wykres 4). Przeciętnie co czwarta kobieta zatrudniona w UE27 może w pewnym stopniu dostosować swój czas pracy do obowiązków prywatnych, jednak zróżnicowanie w tym zakresie między krajami członkowskimi jest wyraźne. W Finlandii 49,6\% kobiet deklaruje możliwość częściowej lub całkowicie elastycznej organizacji czasu pracy (obszar na wykresie zaznaczony deseniem). W Szwecji i w Niemczech analogiczne odsetki wynoszą 43,9\% i 37,6\%, zaś w Polsce jedynie co dziesiąta kobieta w rozważanej grupie wieku może korzystać z tych rozwiązań. W Polsce spośród kobiet w wieku 25-49 lat o statusie pracownika najemnego aż 89,9\% posiada sztywne godziny pracy, natomiast 4,7\% ma określoną liczbę godzin do przepracowania w ciągu dnia przy możliwości zmiany godziny roz- 
poczęcia dnia pracy, 4,0\% pracuje według rozwiązania flexitime, zaś zaledwie 1,2\% indywidualnie ustala plan pracy. Analogiczne odsetki dla krajów EU15 przyjmują odpowiednio wartości: $65,3 \%, 14,9 \%, 11,8 \%$ oraz 3,4\%. Polska sytuuje się więc wśród 5 krajów Unii Europejskiej o najrzadziej spotykanych formach elastycznej organizacji czasu pracy w populacji kobiet w wieku charakteryzującym się największym obciążeniem obowiązkami rodzinnymi związanymi z opieką i wychowywaniem dzieci.

Wykres 3. Odsetek pracowników najemnych pracujących według stałych godzin rozpoczęcia i zakończenia dnia pracy w krajach Unii Europejskiej w 2010 r. ${ }^{*}$

Figure 3. The share of employees having fixed start and end of working day in the European Union countries in 2010.

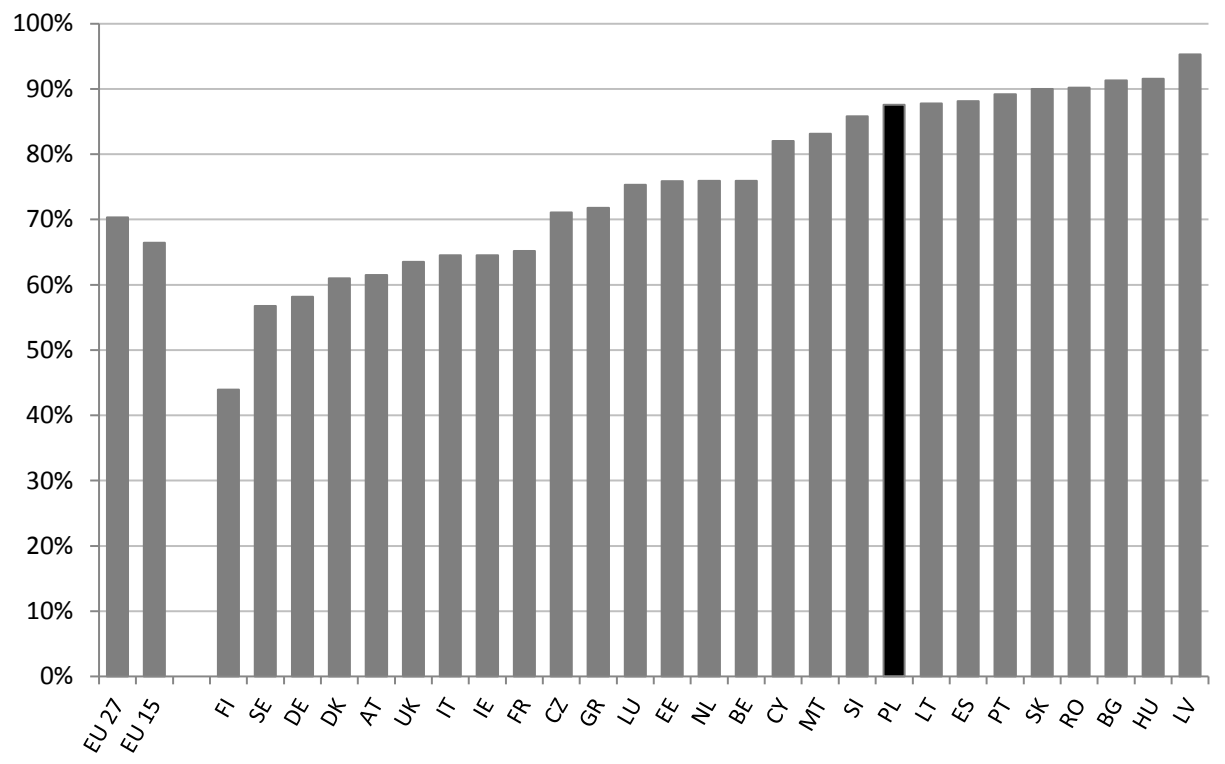

Źródło: opracowanie własne na podstawie danych Eurostat (stan na dzień 21.01.2013); dane LFS ad hoc module Reconciliation between work and family life * Na wykresie nie pokazano wyników dla Łotwy

Source own calculations based on Eurostat data (downloaded on 21st January 2013); EU LFS ad hoc module Reconciliation between work and family life

* The results for Latvia are not shown http://epp.eurostat.ec.europa.eu/portal/page/portal/employment_unemployment_lfs/data/ database 
Wykres 4. Struktura organizacji czasu pracy pracowników najemnych w populacji kobiet w wieku 25-49 lat w krajach Unii Europejskiej w 2010 r.*

Figure 4. Working time arrangements of the female employees aged 25-49 years in the European Union countries in 2010

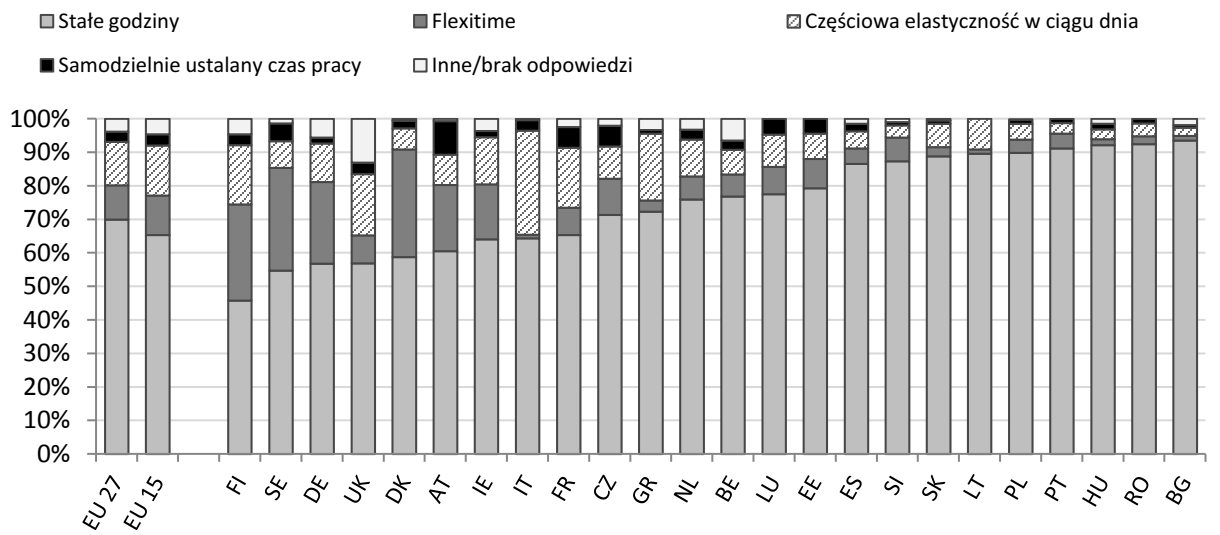

Źródło: opracowanie własne na podstawie danych Eurostat (stan na dzień 21.01.2013); dane LFS ad hoc module Reconciliation between work and family life * Na wykresie nie pokazano wyników dla Łotwy, Malty i Cypru

Source: own calculations based on Eurostat data (downloaded on 21st January 2013); EU LFS ad hoc module Reconciliation between work and family life

* The results for Latvia, Malta and Cyprus are not shown http://epp.eurostat.ec.europa.eu/portal/page/portal/employment_unemployment_lfs/data/ database

Podobnych spostrzeżeń dostarcza analiza częstości deklaracji możliwości i braku możliwości dostosowania godzin rozpoczęcia lub zakończenia czasu pracy do niespodziewanych lub wyjątkowych sytuacji rodzinnych, takich jak np. choroba dziecka, spóźnienie opiekunki, bądź konieczność odebrania dziecka z wycieczki szkolnej. Podobnie jak w przypadku analizy korzystania z elastycznej organizacji czasu pracy, największe odsetki osób nieposiadających możliwości zmiany godziny rozpoczęcia lub zakończenia dnia pracy, nawet w wyjątkowych przypadkach, występują głównie w krajach postkomunistycznych (Wykres 5). W Polsce aż 40,5\% pracowników najemnych w wieku 15-64 lat nie ma możliwości zmiany godziny rozpoczęcia lub zakończenia dnia pracy z powodów rodzinnych, podczas gdy w Holandii lub Wielkiej Brytanii odsetek ten nie przekracza 10\%. W Polsce jedynie 21,2\% pracowników najemnych ma możliwość dostosowania godzin rozpoczęcia lub zakończenia dnia pracy, podczas gdy średnia dla UE27 wynosi 51,1\%. Najdogodniejsza sytuacja z punktu widzenia korzystania $\mathrm{z}$ tego rozwiązania ułatwiającego łączenie obowiązków rodzinnych i zawodowych występuje w Holandii $(85,0 \%)$, Danii i Wielkiej Brytanii (75,0\%) oraz Francji (74,1\%). 
Wykres 5. Odsetek pracowników najemnych nieposiadających możliwości zmiany godzin rozpoczęcia lub zakończenia dnia pracy $\mathrm{z}$ powodów rodzinnych $\mathrm{w}$ krajach Unii Europejskiej w 2010 r.

Figure 5. The share of employees not having the possibility to vary start or end of working day for family reasons in the European Union countries in 2010.

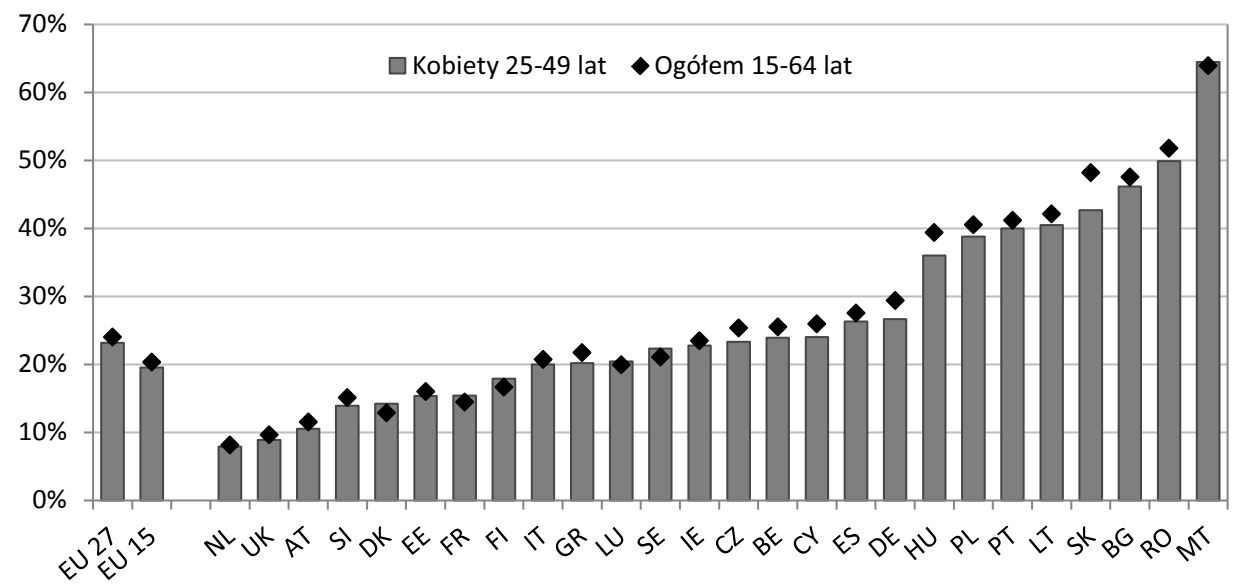

Źródło: opracowanie własne na podstawie danych Eurostat (stan na dzień 21.01.2013); dane LFS ad hoc module Reconciliation between work and family life * Wykres nie uwzględnia Łotwy.

Source: own calculations based on Eurostat data (downloaded on 21st January 2013); EU LFS ad hoc module Reconciliation between work and family life

* The results for Latvia are not shown on the figure http://epp.eurostat.ec.europa.eu/portal/page/portal/employment_unemployment_lfs/data/ database

Opieka nad dzieckiem może także wiązać się z wystąpieniem sytuacji, w których rodzic lub opiekun nie jest w stanie wykonywać pracy zawodowej w danym dniu. Pewne rodzaje formalnej lub nieformalnej organizacji czasu pracy mogą pozwolić opiekunom na wzięcie dnia wolnego i odpracowanie go w innym terminie lub $\mathrm{w}$ ramach nadgodzin (przed lub po wystąpieniu konieczności skorzystania $\mathrm{z}$ dnia wolnego), nie sięgając po dni wolne z urlopu wypoczynkowego. Możliwość ta występuje co prawda rzadziej w krajach UE niż możliwość zmiany godziny rozpoczęcia/ zakończenia dnia pracy, jednak nadal średnio 39,3\% pracowników zatrudnionych w krajach UE27 może korzystać z tego rozwiązania, chociaż 23,2\% może czynić to tylko w wyjątkowych przypadkach. W Polsce odsetki te wyniosły odpowiednio $14,0 \%$ i $25,1 \%$. Oznacza to, że $61,0 \%$ pracowników najemnych $(61,8 \%$ kobiet w wieku 25-49 lat) nie posiada w ogóle możliwości odpracowania dnia wolnego. Wyższy udział tych pracowników obserwuje się tylko w Portugalii, na Węgrzech, Malcie i Cyprze (Wykres 6). 
Wykres 6. Odsetek pracowników najemnych nieposiadających możliwości zorganizowania czasu pracy w sposób pozwalający na wzięcie dnia wolnego bez wykorzystywania urlopu w przypadku nagłej sytuacji rodzinnej w krajach Unii Europejskiej w 2010 r.

Figure 6. The share of employees not having the possibility to take a day off without using holidays in case of urgent family situation in the European Union countries in 2010.

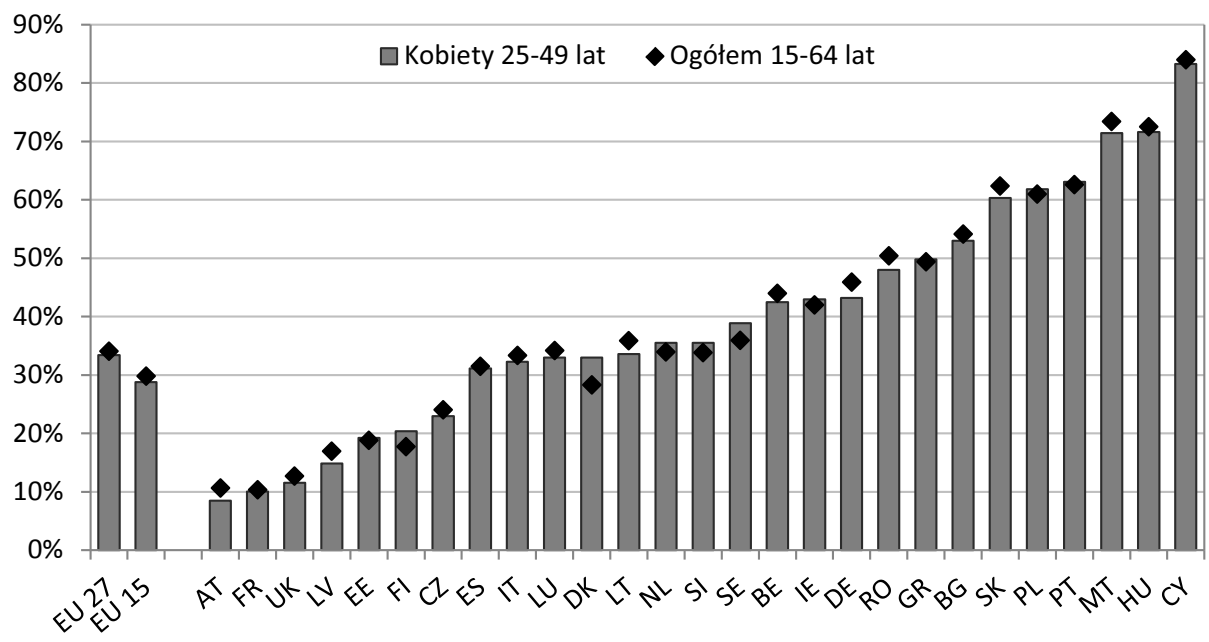

Źródło opracowanie własne na podstawie danych Eurostat (stan na dzień 21.01.2013); dane LFS ad hoc module Reconciliation between work and family life

Source: own calculations based on Eurostat data (downloaded on 21st January 2013); EU LFS ad hoc module Reconciliation between work and family life

http://epp.eurostat.ec.europa.eu/portal/page/portal/employment_unemployment_lfs/data/ database

Powyższe wyniki analizy wyraźnie wskazują, że organizacja czasu pracy w Polsce na tle innych krajów europejskich charakteryzuje się bardzo niskim stopniem elastyczności, co określa duże trudności łączenia pracy zawodowej z obowiązkami rodzinnymi. Podobną sytuację obserwuje się w krajach Europy Środkowo-Wschodniej, choć Czechy i Estonia zdają się być bliższe krajom Europy Zachodniej.

\section{WYKONYWANIE PRACY POZA BIUREM}

W świetle badań międzynarodowych Polska wypada stosunkowo korzystnie na tle innych krajów, jeśli chodzi o możliwości wykonywania pracy z domu. W $2010 \mathrm{r}$. blisko 15\% ogółu pracujących kobiet w wieku 25-49 lat miało możliwość (zwykle lub czasami) wykonywania obowiązków zawodowych pracując z domu. W dużym stopniu z rozwiązania tego korzystają osoby samozatrudnione, co trzecia samozatrudniona kobieta w wieku 25-49 lat może wykonywać pracę z domu (16,8\% ma 
taką możliwość zwykle i 16,7\% czasami). Jednak w przypadku samozatrudnienia prowadzenie działalności gospodarczej w domu może wynikać z wysokich kosztów wynajmu i utrzymania stosownych pomieszczeń poza domem, nie zaś z preferencji pracującego.

W populacji pracowników najemnych możliwości pracy z domu są ograniczone, w Polsce w 2010 r. zaledwie co 10-ta kobieta w wieku 25-49 lat mogła przynajmniej czasami skorzystać z tego rozwiązania (Wykres 7). Jednocześnie warto podkreślić, iż częstość odpowiedzi wskazujących na posiadanie możliwości pracy z domu jest wyższa wśród kobiet niż wśród mężczyzn.

Wykres 7. Odsetek kobiet pracujących z domu, w populacji kobiet o statusie pracownika najemnego w wieku 25-49 lat w $2010 \mathrm{r}^{*}$

Figure 7. The share of women working from home among female employees aged 25-49 years in 2010.

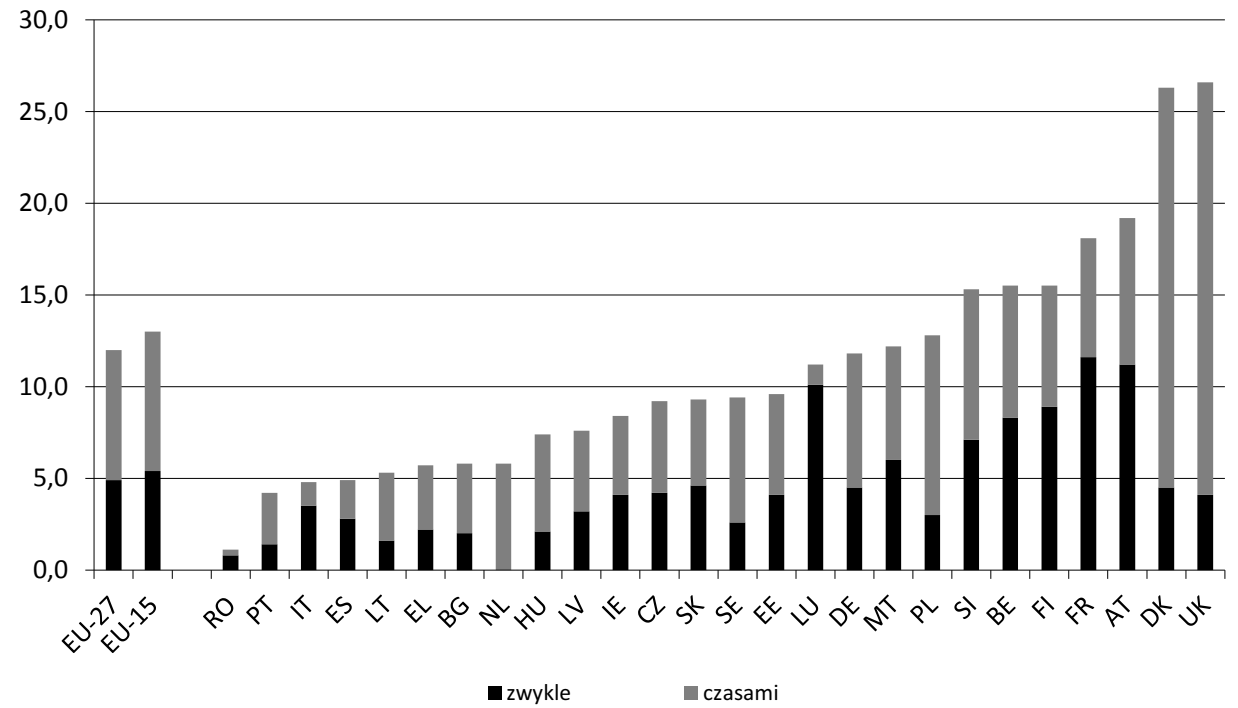

Źródło opracowanie własne na podstawie danych Eurostat (stan na dzień 06.02.2013); dane BAEL * dla Holandii oraz Rumunii brak jest szacunków liczebności osób pracujących czasami z domu, zaś dla Cypru, Łotwy, Bułgarii i Portugalii - szacunków liczby osób pracujących zwykle z domu.

Source: own calculations based on Eurostat data (downloaded on $6^{\text {th }}$ February 2013); EU LFS annual results

* There are no estimates for the Netherlands and Romania regarding the employed working sometimes from home, while for Cyprus, Latva, Bulgaria and Portugal numbers of the employed working usually from home are missing $\mathrm{http} / / /$ epp.eurostat.ec.europa.eu/portal/page/portal/employment_unemployment_lfs/data/ database 
Wyniki dla Polski w odniesieniu do możliwości wykonywania obowiązków zawodowych z domu zbliżone są do średniej dla wszystkich krajów Unii Europejskiej. W niektórych krajach takich jak Wielka Brytania, Dania, czy Szwecja można zaobserwować, że częściej niż co piąta kobieta pracuje (przynajmniej czasami) $\mathrm{z}$ domu, co sugeruje, że w Polsce to rozwiązanie także mogłoby w przyszłości stać się częściej wykorzystywane.

\section{ZMIANY KORZYSTANIA Z ELASTYCZNYCH FORM ORGANIZACJI PRACY W LATACH 2005-2010}

Przedstawione wyżej wyniki pokazują, że w Polsce godzenie życia zawodowego z życiem rodzinnym jest utrudnione ze względu na warunki zatrudnienia i organizację pracy. Jednak nie oznacza to, iż nie obserwowuje się poprawy sytuacji. W celu identyfikacji zmian wykorzystano dane pochodzące $\mathrm{z}$ analogicznego badania „Praca a obowiązki rodzinne” przeprowadzonego w 2005 r. Porównanie wyników obu badań pokazuje, że w 2010 r. możliwości dostosowania organizacji czasu pracy do obowiązków rodzinnych, w szczególności w przypadku wystąpienia nagłych lub wyjątkowych sytuacji rodzinnych, były większe niż 5 lat wcześniej (Wykres 8). W 2005 r. 46,5\% kobiet w wieku 25-49 lat (45,5\% ogółu pracowników) o statusie pracowników najemnych mogło zmienić (na ogół lub w wyjątkowym przypadku) godziny rozpoczęcia lub zakończenia dnia pracy w nagłej sytuacji rodzinnej, zaś w 2010 r. odsetek ten wzrósł do 61,2\% (dla ogółu pracowników do $59,5 \%$ ). W odniesieniu do możliwości wzięcia dnia wolnego bez wykorzystywania urlopu, analogiczny wzrost wyniósł 11,3 p.p. (z $26,9 \%$ do $38,2 \%$ ) dla kobiet w wieku 25-49 lat (a dla ogółu pracowników z 27,6\% do 39,1\%). Należy jednak wskazać, iż zarówno w 2005 r. jak i w 2010 r. sytuacja kobiet w odniesieniu do elastyczności organizacji czasu pracy nie różniła się istotnie od sytuacji ogółu pracowników najemnych.

Możliwości pracy z domu nie zmieniły się w badanych latach (odsetek zatrudnionych kobiet $\mathrm{w}$ wieku 25-49 lat mających możliwość telepracy zwykle lub czasami wyniósł w 2005 r. 10,1\%, a w 2010 r. - 10,8\%). Korzystanie z zatrudnienia w niepełnym wymiarze czasu pracy wykazuje tendencję spadkową. Udział zatrudnionych w niepełnym wymiarze czasu zmniejszył się z 9,8\% w 2005 r. do 7,6\% w 2010 r. w populacji osób pracujących w wieku 15-64 lat. W tym samym czasie odsetek osób zatrudnionych w niepełnym wymiarze czasu pracy w Unii Europejskiej (zarówno EU27 jak i EU15) nieznacznie wzrósł. Podobna prawidłowość obserwowana jest dla populacji kobiet $\mathrm{w}$ wieku 25-49 lat: udział kobiet pracujących w niepełnym wymiarze czasu pracy spadł do $8,1 \%$ wobec $10,2 \%$ w $2005 \mathrm{r}$. 
Wykres 8. Możliwości dostosowania organizacji czasu pracy zawodowej do nagłych lub wyjątkowych sytuacji rodzinnych wśród kobiet w wieku 25-49 lat o statusie pracownika najemnego w Polsce w 2005 i 2010 r.

Figure 8. The possibility to adjust the working time arrangements to urgent or exceptional family situations among female employees aged 25-49 years in 2005 and 2010 in Poland.

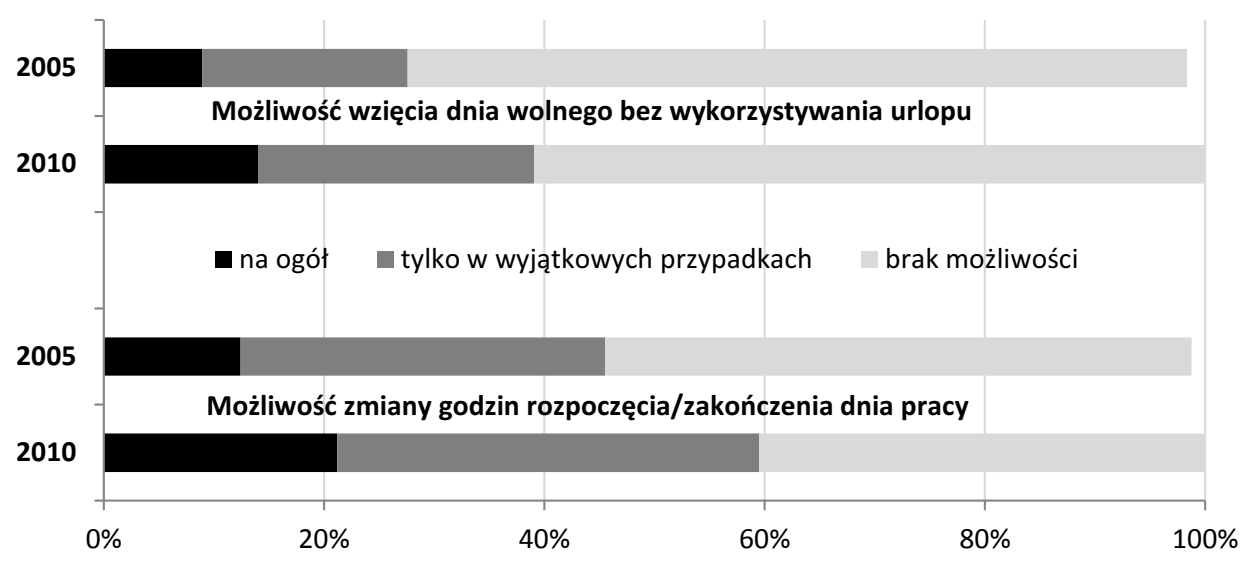

Źródło: Opracowanie własne na podstawie danych GUS z modułów BAEL: „Praca a obowiązki rodzinne w 2005 r.”, „Praca a obowiązki rodzinne w 2010 r.”

${ }^{*} \mathrm{~W}$ badaniu z 2005 r. brak jest informacji dla 2,3\% rozpatrywanej populacji i stąd przedstawione odsetki odpowiedzi nie sumują się do $100 \%$

Source: own calculations based on GUS data from PL LFS ad hoc modules "Reconciliation between work and family life in 2005" and "Reconciliation between work and family life in 2010"

* data from 2,3\% of respondents in the 2005 survey is missing and therefore the presented percentages do not sum to $100 \%$.

Warto podkreślić, że analizowane tutaj rozwiązania w zakresie dostosowania czasu pracy do nagłych lub wyjątkowych sytuacji rodzinnych dotyczą rzeczywistych możliwości, a nie formalnych uregulowań prawnych. Stąd niskie odsetki pracowników w Polsce deklarujących istnienie tylko w wyjątkowych sytuacjach takich rozwiązań. Odzwierciedlają one nie tylko niewykorzystanie istniejących możliwości przewidzianych w regulacjach prawnych (np. z powodu nieznajomości swoich praw przez pracowników), ale także jakość relacji między pracownikami (możliwość zastępstw) oraz między pracownikami a przełożonymi lub pracodawcami (wyrozumiałość, chęć reorganizacji zadań, zaufanie). 


\section{PROPOZYCJE NOWYCH ROZWIĄZAŃ PRAWNYCH}

\section{ZMNIEJSZANIE WYMIARU CZASU PRACY}

W Polsce możliwość podejmowania pracy w niepełnym wymiarze była przewidziana w kodeksie pracy jeszcze przed zmianą ustroju w 1989 r. W warunkach gospodarki centralnie planowanej polityka rynku pracy była zorientowana na maksymalizację (nominalnego) wykorzystania zasobów pracy, co ograniczało korzystanie $\mathrm{z}$ tej formy zatrudnienia. Jednak od wprowadzenia gospodarki rynkowej udział pracowników zatrudnionych w niepełnym wymiarze wzrósł w Polsce w bardzo niewielkim stopniu. Taki stan rzeczy wiąże się z oddziaływaniem wielu czynników makroekonomicznych oraz instytucjonalnych (OECD 2002, Eurofund 2007). Spośród wymienianych w literaturze przedmiotu najważniejszych barier rozpowszechnienia pracy w niepełnym wymiarze można wskazać przede wszystkim sektorową strukturę gospodarki. Zatrudnienie w niepełnym wymiarze czasu pracy najczęściej stosuje się w sektorze usługowym, który jest nadal słabiej rozwinięty w Polsce i innych krajach Europy Środkowo-Wschodniej niż w krajach Europy Zachodniej. Ponadto z punktu widzenia perspektyw rozpowszechniania się zatrudnienia $\mathrm{w}$ niepełnym wymiarze istotnym czynnikiem jest poziom wynagrodzeń, opodatkowania oraz świadczeń dla młodych rodziców. Przejście na zatrudnienie w niepełnym wymiarze w związku ze sprawowaniem opieki nad dzieckiem wiąże się z obniżeniem wynagrodzenia, co przy stosunkowo niskich płacach w Polsce, niskim stopniu progresji podatkowej oraz wysokich kosztach korzystania z instytucjonalnej opieki nad dzieckiem może być dla wielu rodziców nieopłacalne finansowo (Baranowska i Lewandowski 2007, Matysiak 2007). Ponadto barierą szerszego korzystania z zatrudnienia w niepełnym wymiarze czasu pracy może być jego ograniczona opłacalność z perspektywy pracodawców. Pracodawcy będą niechętnie stosować zatrudnienie w niepełnym wymiarze, jeśli koszty wyposażenia stanowisk pracy, przeszkolenia pracowników oraz składek na ubezpieczenia społeczne będą wyższe w przypadku zatrudnienia kilku osób w niepełnym wymiarze niż w przypadku równoważnej liczby osób zatrudnionych na pełen etat.

\section{ELASTYCZNY CZAS PRACY}

W Polsce wiele rozwiązań służących uelastycznieniu czasu pracy i dostosowania go do potrzeb, między innymi, osób obciążonych obowiązkami rodzinnymi zostało usankcjonowane w nowelizacji kodeksu pracy w 2003 roku (Machol-Zajda 2003). Formalnie w polskim Kodeksie Pracy nie funkcjonuje rozwiązanie określane w literaturze przedmiotu jako indywidualne konta czasu pracy, ale pracodawcy dysponują pewną swobodą w zakresie elastycznego gospodarowania czasem pracy pracowników. Pracodawcy mogą przyznawać pracownikom czas wolny (zamiast 
finansowej rekompensaty) w zamian za czas przepracowany ponad ustawową normę, która wynosi osiem godzin na dobę i jednocześnie 40 godzin w tygodniu w skali okresu rozliczeniowego. Okres rozliczeniowy wynosi standardowo 4 miesiące, jednak w pewnych sektorach gospodarczych, w których występują nietypowe warunki techniczne mające wpływ na przebieg procesów pracy, dopuszczalne jest stosowanie dłuższych okresów rozliczeniowych, nawet do wysokości do 12 miesięcy².

W świetle opinii organizacji pracodawców oraz w świetle wciąż stosunkowo niskiego wykorzystania powyższych rozwiązań, w Polsce udoskonalić można obowiązujące przepisy. Na przykład, pracodawcy zwracają uwagę na funkcjonujący system obliczania wymiaru czasu pracy, oparty na dwóch normach: dobowej oraz tygodniowej (Lewiatan 2012). Modyfikacja tych przepisów mogłaby, w ich opinii, pozwolić lepiej dostosowywać organizację pracy zarówno do potrzeb pracowników i pracodawców. W szczególności w ocenie pracodawców skreślenie dobowej normy czasy pracy (i pozostawienie jedynie tygodniowej 40 godzinnej normy oraz zasady co najmniej 11-godzinnego nieprzerwanego odpoczynku) mogłoby zwiększyć elastyczność gospodarowania czasem pracy. W wyniku tak dokonanych zmian pracodawcy mieliby większą swobodę określania długości dnia pracy (co oczywiście niekoniecznie oznacza, że rozwiązanie to wykorzystywaliby dla spełnienia potrzeb pracowników próbujących łączyć pracę zawodową z obowiązkami opiekuńczymi).

Dotychczasowa debata publiczna dotycząca reform w zakresie regulacji norm czasu pracy oraz długości okresów rozliczeniowych motywowana była głównie troską o zapewnienie przedsiębiorstwom elastyczności w gospodarowaniu zasobami pracy w dynamicznie zmieniających się warunkach gospodarczych, a zwłaszcza przy wahaniach popytu na dobra i usługi. Znacznie mniej uwagi poświęcano sposobom dostosowania przepisów prawa pracy, by pracownicy mogli w razie konieczności skracać czas pracy w dni, w których wymagałaby tego opieka nad dziećmi, i wyrównywać przepracowaną liczbę godzin w dni, gdy konieczność ich zaangażowania w obowiązki rodzinne byłaby mniejsza. Jednak takie rozwiązania mogą budzić obawy o narzucanie pracownikom niekorzystnego, dziennego czasu pracy. Ponadto wielu pracujących, w szczególności w regionach o wysokim bezrobociu, musiałoby zaakceptować je z obawy przed utratą pracy. Rozwiązania takie mogłyby okazać się korzystne tylko dla pracodawców. Należy jednocześnie wyraźnie zaznaczyć, że wprowadzenie zmian legislacyjnych, które byłyby korzystne dla pracowników, ale nie uwzględniałyby interesów pracodawców mogłoby przynieść skutki odwrotne do oczekiwanych i doprowadzić do dyskryminacji przy zatrudnianiu pracowników, którzy sprawują opiekę nad dziećmi. Wprowadzenie takich modyfikacji musiałaby zostać przedyskutowane $\mathrm{w}$ dialogu partnerów społecznych oraz organizacji pozarządowych.

\footnotetext{
2 Według stanu prawnego w sierpniu 2013 r.
} 
Wykonywanie pracy poza biurem, określane formalnie jako telepraca, zostało wprowadzone do Kodeksu Pracy w nowelizacji z 2007 r. Zarówno w literaturze przedmiotu jak i w raportach organizacji zrzeszających pracodawców, zwraca się uwagę na pewne niedoskonałości funkcjonujących obecnie przepisów, które mogą być zmienione w celu ułatwienia wykorzystania tej formy zatrudnienia.

Po pierwsze, przepisy kodeksu odnoszą się do osób, które cały czas poświęcany na wykonywanie obowiązków zawodowych spędzają w domu (lub innym miejscu pracy nie zlokalizowanym $\mathrm{w}$ siedzibie pracodawcy). W świetle obowiązujących obecnie przepisów nie jest natomiast jasny status osób, które poza biurem pracują jedynie przez część swojego czasu pracy (Baranowska i Lewandowski 2008). Trudno jest jednoznacznie określić, czy takie osoby z formalnego punktu widzenia wykonują telepracę, czy też należy ich traktować jako „zwykłych” pracowników. Jest to dość istotne, ponieważ w Polsce ponad połowa wszystkich osób pracujących z domu, telepracę stosuje tylko sporadycznie, a nie regularnie (Wykres 7).

Po drugie, kodeks pracy nakłada na pracodawcę obowiązek wyposażenia pracownika wykonującego pracę poza biurem w odpowiedni sprzęt. Pracodawca, w świetle obowiązujących przepisów, musi przygotować takiej osobie „stanowisko pracy”, ubezpieczyć sprzęt oraz zapewnić warunki techniczne jego funkcjonowania. Oznacza to - z punktu widzenia pracodawcy - konieczność poniesienia dodatkowych kosztów materialnych i organizacyjnych i w związku z tym może zniechęcać do stosowania telepracy, zwłaszcza jeśli miałaby ona służyć sporadycznemu uzupełnianiu tradycyjnej pracy w biurze (Baranowska i Lewandowski 2008, Uścińska et al. 2011).

W literaturze przedmiotu zwraca się także uwagę na niedostosowanie przepisów z zakresu bezpieczeństwa i higieny pracy w kontekście telepracy (Uścińska et al. 2011). W świetle obowiązujących przepisów nie jest jasne, czy przed wprowadzeniem telepracy inspektor musi udać się do miejsca zamieszkania telepracownika i ocenić ryzyko zawodowe na stanowisku pracy oraz ustalić, czy są spełnione wymogi bezpieczeństwa i higieny pracy (Polska Konfederacja Pracodawców Prywatnych Lewiatan 2012). Z punktu widzenia możliwości upowszechnienia telepracy korzystny byłby przegląd i modyfikacja przepisów utrudniających stosowanie telepracy z uwzględnieniem obowiązków związanych z bezpieczeństwem i higieną pracy.

W świetle badań międzynarodowych ważnym ograniczeniem szerszego wykorzystania telepracy jest zabezpieczenie informacji przekazywanych pomiędzy stanowiskiem pracy telepracownika a siedzibą pracodawcy (Margherita et al. 2009). Wiele przedsiębiorstw ma obawy, że stosujący nieuczciwe metody konkurencji mogą wykorzystać brak odpowiednich zabezpieczeń przekazywanych danych, oprogramowania oraz kanałów komunikacji. Takie obawy wyrażali, między innymi, przedsiębiorcy w Polsce, wskazując na trudności finansowe związane $\mathrm{z}$ inwestowaniem w odpowiednie narzędzia techniczne oraz ochronę danych (Bednarski i Machol- 
-Zajda 2003). Inwestycja w odpowiednie zabezpieczenia byłaby dodatkowym kosztem, który pracodawcy musieliby ponieść $\mathrm{z}$ tytułu oferowania swoim pracownikom $\mathrm{z}$ elastycznej formy zatrudnienia jaką jest telepraca.

\section{WNIOSKI KOŃCOWE}

Przedstawione wyniki analiz pozwalają na sformułowanie wniosku, że w Polsce można potencjalnie zwiększyć zakres wykorzystywania rozwiązań, które ułatwiają dostosowanie organizacji czasu pracy do obowiązków rodzinnych. Świadczą o tym wyniki porównań międzynarodowych wskazujące, że w innych krajach udało się stworzyć warunki, w których pracownicy częściej mogą organizować czas i wymiar pracy tak, by zredukować konflikt między wykonywaniem obowiązków zawodowych i rodzinnych. Poprawia to nie tylko jakość życia i satysfakcję z życia, w tym życia rodzinnego, ale także stwarza lepsze warunki dla rodzicielstwa (Kotowska et al. 2010). W świetle przedstawionych statystyk wyróżniają się takie kraje jak Holandia, kraje skandynawskie, a także Austria, Niemcy, Wielka Brytania, Belgia, Francja. W tych krajach jedynie Austria i Niemcy mają niską dzietność tj. przekrojowy współczynnik dzietności nie przekracza 1,5 dziecka na kobietę w wieku rozrodczym. Pozostałe charakteryzuje dzietność stosunkowo wysoka jak na warunki europejskie (powyżej 1,7 dziecka na kobietę). Warto zatem czerpać z pozytywnych doświadczeń tych krajów, choć nie wszystkie rozwiązania mogą być automatycznie implementowane w Polsce np. ze względu na różnice w otoczeniu instytucjonalno-prawnym, czy też uwarunkowania kulturowe.

Wprowadzenie w Polsce zmian instytucjonalnych, w szczególności zmian w prawie pracy, wymagałoby dialogu z organizacjami pracodawców. Do udziału w tym dialogu powinni zostać zaproszeni także przedstawiciele partnerów społecznych i organizacji pozarządowych, które reprezentują potrzeby i interesy rodziców.

Należy też wyraźnie zaznaczyć, że wprowadzenie regulacji z zakresu prawa pracy pozwalających elastycznie dopasowywać organizację pracy zawodowej do obowiązków rodzinnych nie może zastąpić rozwiązań dotyczących stworzenia rodzicom warunków do swobodnego korzystania z instytucjonalnej opieki nad dzieckiem. Praca $w$ niepełnym wymiarze, elastyczny czas pracy czy też praca $\mathrm{z}$ domu mogą być rozpatrywane jako rozwiązania komplementarne w stosunku do tanich i szeroko dostępnych usług edukacyjno-opiekuńczych odpowiedniej jakości. Tylko konsekwentne wprowadzanie rozwiązań zmieniających warunki podejmowania decyzji o dziecku oraz wychowywania dzieci w Polsce stworzy warunki dla trwałej poprawy wskaźników płodności (Dobry klimat dla rodziny 2013). 


\section{PODZIĘKOWANIA}

Niniejszy tekst powstał na podstawie ekspertyzy dotyczącej warunków godzenia pracy zawodowej z opieką nad dziećmi w Polsce przygotowanej na zlecenie Kancelarii Prezydenta RP. Chciałybyśmy serdecznie podziękować prof. Irenie E. Kotowskiej za sugestie i wskazówki przekazane w trakcie naszej pracy nad tym opracowaniem. Ostateczna wersja artykulu została przygotowana podczas stypendium naukowego $\mathrm{dr}$ Baranowskiej-Rataj w Wydziale Socjologii na Uniwersytecie Umeå. Autorka pragnie podziękować tej instytucji za wsparcie dla jej pracy naukowej.

\section{LITERATURA}

Aliaga Ch., 2005, Gender gaps in the reconciliation between work and family life, "Statistics in Focus", Population and Social Conditions nr 4 Eurostat, Luxemburg.

Baranowska A., 2007, Decyzje prokreacyjne - preferencje a realizacja, [w:] I. E. Kotowska, U. Sztanderska, I. Wóycicka, Aktywność zawodowa i edukacyjna a obowiqzki rodzinne $w$ Polsce $w$ świetle badań empirycznych (s. 423-437), Wydawnictwo Naukowe Scholar, Warszawa.

Baranowska A., Lewandowski P., 2008, Adaptacyjność do zmian gospodarczych, [w:] M. Bukowski (red.), Zatrudnienie $w$ Polsce 2007. Bezpieczeństwo na elastycznym rynku pracy, Departament Analiz Ekonomicznych i Prognoz, Ministerstwo Pracy i Polityki Społecznej, Warszawa.

Baranowska-Rataj A., Matysiak A., 2012, Czy znamy lekarstwo na niska dzietność? Międzynarodowe badania ewaluacyjne na temat polityki rodzinnej, „Polityka Społeczna”, 7/2012, 9-14.

Bednarski M., Machol-Zajda L., 2003, Telepraca, [w:] E. Kryńska (red.), Elastyczne formy zatrudnienia i organizacji pracy a popyt na prace w Polsce, Instytut Pracy i Spraw Socjalnych, Warszawa.

Boulin J.-Y., Lallement M., Messenger J., Michon F. (red.), 2006, Decent working time: New trends, new issues, International Labour Office, Geneva.

Dobry klimat dla rodziny, Program Polityki Rodzinnej Prezydenta RP, Warszawa, 2013.

Głogosz D., 2007, Kobiety zatrudnione w niepetnym wymiarze czasu pracy skutki dla życia rodzinnego i zawodowego, Instytut Pracy i Spraw Socjalnych, Warszawa.

GUS, Praca a obowiqzki rodzinne w 2005 r., Warszawa, GUS.

GUS, Praca a obowiazki rodzinne w 2010 r., Warszawa, GUS.

Kotowska I. E., 2005, Work and parenthood: main findings of comparative data analysis and some policy implications, "Studia Demograficzne", nr 2/148, 54-82.

Kotowska I.E., U.Sztanderska, I.Wóycicka, 2009, Scenariusz modernizacji polityki spolecznej. Stymulowanie wzrostu aktywności ekonomicznej i dzietności kobiet, [w:] I.E. Kotowska (red.), 2009, Strukturalne i kulturowe uwarunkowania aktywności zawodowej kobiet w Polsce, Wydawnictwo Naukowe SCHOLAR, 261-280.

Kotowska I.E., Matysiak A., Pailhé A., Solaz A., Styrc M., Vignoli D., 2010, Second European Quality of Life Survey: Family Life and Work, European Foundation for the Improvement of Living and Working Conditions, Office for Official Publications of the European Communities, Luxembourg.

Machol-Zajda L., 2003, Elastyczność czasu pracy w prawodawstwie krajów UE i Polski, „Zarządzanie Zasobami Ludzkimi”, nr 3-4, 69-83.

Machol-Zajda L., 2008, Godzenie życia zawodowego i pozazawodowego - poszukiwanie rozwiazań organizacyjnych i czasowych, [w:] C. Sadowska-Snarska, L. Tchon, Godzenie pracy z rodzina w kontekście aktywizacji zawodowej kobiet, Wydawnictwo Wyższej Szkoły Ekonomicznej w Białymstoku, Białystok. 
Margherita A., O'Dorchai S., Bosch J., 2009, Reconciliation between work, private and family life in the European Union, Eurostat, Luxemburg.

Matysiak A., 2007, Indywidualne przestanki zwiększenia aktywności zawodowej [w:] I. E. Kotowska, U. Sztanderska, I. Wóycicka (red.), Aktywność zawodowa i edukacyjna a obowiqzki rodzinne $w$ Polsce w świetle badań empirycznych (s. 383-403), Wydawnictwo Naukowe Scholar, Warszawa.

Matysiak A., 2007, Organizacja czasu pracy i opieki, [w:] I. E. Kotowska, U. Sztanderska, I. Wóycicka (red.), Aktywność zawodowa i edukacyjna a obowiazki rodzinne $w$ Polsce $w$ świetle badań empirycznych (s. 345-382), Wydawnictwo Naukowe Scholar, Warszawa.

Matysiak A., Steinmetz S., 2008, Finding their way? Female employment patterns in West Germany, East Germany, and Poland, "European Sociological Review", nr 24/3, 331-345.

McDonald P., 2006, An assessment of policies that support having children from the perspectives of equity, efficiency and efficacy, "Vienna Yearbook of Population Research", nr 4/1, 213-234.

Mynarska M., 2011, Kto planuje mieć dzieci w Polsce do 2015 roku?, „Studia Demograficzne”, nr 1/159, 75-98.

OECD, 2001, The well-being of nations. The Role of Human and Social Capital, Paryż, OECD.

OECD, 2002, Employment Outlook 2002, Paryż, OECD.

Polska Konfederacja Pracodawców Prywatnych Lewiatan, 2012, Czarna lista barier dla rozwoju przedsiębiorczości, Polska Konfederacja Pracodawców Prywatnych Lewiatan, Warszawa.

Pongrácz M., Spéder Z., 2008, Attitudes towards forms of partnership, [w:] Ch. Höhn, D. Avramov, I. E. Kotowska (red.), People, Population Change and Policies: Lessons from the Population Policy Acceptance Study (s. 93-112), Springer, Berlin.

Riedmann A., Bielenski H., Szczurowska T., Wagner A., 2007, Working time and work-life balance in European companies, European Foundation for the Improvement of Living and Working Conditions, Dublin.

Skarzyński M., 2007, Elastyczne formy pracy w praktyce doradczej, Białystok, Wydawnictwo Wyższej Szkoły Ekonomicznej W Białymstoku, Białystok.

Stankuniene V., Maslauskaite A., 2008, Family transformations in the post-communist countries: Attitudes toward changes and the ideational shift, [w:] Ch. Höhn, D. Avramov, I. E. Kotowska (red.), People, population change and policies: Lessons from the Population Policy Acceptance Study (s. 113-137), Springer, Berlin.

Titkow A., Duch-Krzystoszek D., 2009, Intencje i decyzje prokreacyjne w spoleczeństwie polskim a polityka przyjazna prokreacji, „Studia Demograficzne”, nr 1/155, 70-97.

Uścińska G., Petelczyc J., Roicka P., 2011, Diagnoza sytuacji osób w wieku 45+ na rynku pracy $w$ Polsce $i$ w wybranych krajach UE na podstawie danych zastanych. Aspekt prawny, Instytut Pracy i Spraw Socjalnych, Warszawa. 


\title{
RECONCILIATION BETWEEN ORGANIZATION \\ OF WORKING TIME AND FAMILY \\ RESPONSIBILITIES IN POLAND
}

\begin{abstract}
This paper presents a diagnosis of reconciliation of work and parenthood in Poland based on the data from the European Labour Force Survey ad hoc module "Reconciliation between work and family life" carried out in 2010. These data provide information on the following options of combining work with parenthood duties: (1) part-time work (2) flexible arrangements of working time (3) distance work. We compare the conditions for combining work with parenthood duties in Poland with opportunities observed in other European countries. We also show to what extent the conditions for reconciliation of work and parenthood in Poland have improved in time. We make an overview of legal regulations related to combining work with childcare duties and indicate the opportunities for improvement of these policies.
\end{abstract}

Keywords: work-life balance, reconciliation of work and family duties, flexibility. 